KS. WIESEAW SZUCA

\title{
KSIĄDZ FELIKS BOLT - DUSZPASTERZ, PATRIOTA I SPOŁECZNIK
}

Przeżywana w tym roku 100. rocznica odzyskania niepodległości przez Polskę jest dobrą okazją do przypomnienia ważnych wydarzeń z polskiej historii. Jednym z najbardziej tragicznych był okres drugiej wojny światowej. Był to czas masowych mordów i wielkich prześladowań ludności polskiej, zarówno ze strony Niemców jak i Sowietów. Grupą szczególnie uciskaną byli duchowni. Terror niemiecki skierowany w stronę Kościoła wywołał wielkie spustoszenie w szeregach kapłańskich. Przed wybuchem wojny w 21 polskich diecezjach pracowało 10071 księży świeckich. Spośród nich, aż 1811 zostało zamordowanych, m.in. w komorach gazowych i hitlerowskich katowniach ${ }^{1}$. Najwięcej kapłanów zginęło z diecezji chełmińskiej. Spośród 701 księży tej diecezji, podczas wojny zginęło 312, z czego 215 zostało rozstrzelanych już jesienią 1939 roku² $^{2}$ Wielu kapłanów zostało zamordowanych za swoją wiarę, ale też za swoją działalność społeczno-patriotyczną. Jednym z nich jest znany działacz społeczny na Pomorzu ks. Feliks Bolt.

\section{RYS BIOGRAFICZNY}

Urodził się 7 stycznia 1864 roku w Barłożnie na Kociewiu. Jego rodzicami byli Józef Bolt i Joanna z domu Grajkowska. Mieli oni dziewięcioro dzieci. Feliks był siódmym dzieckiem z kolei. Miał pięć sióstr oraz trzech braci. W swojej rodzinie otrzymał dobre wychowanie w duchu katolickim i patriotycznym. Rodzice od samego początku dbali o dobre wykształcenie młodego Feliksa. Podstawowe wykształcenie zdobył w swoim domu rodzinnym. Od 11 września 1874 do

Por. S. Podlewski, Wierni Bogu i Ojczyźnie. Duchowieństwo katolickie w walce o niepodległość Polski w II Wojnie Światowej, Novum, Warszawa 1982, s. 11.

2 Por. W. Wielgoszewski, Męczeństwo kapłanów Kościoła chełmińskiego. Wierni aż do końca, „Niedziela” 45(2006), s. 21. 
16 kwietnia 1882 roku kształcił się w pelplińskim Collegium Marianum³ ${ }^{3}$ Następnie był uczniem gimnazjum w Chełmnie ${ }^{4}$. Tutaj należał do tajnej organizacji filomackiej. Przyczynił się też do założenia koła filomackiego w Toruniu. Za tę działalność patriotyczną został wydalony ze szkoły, dlatego egzamin maturalny złożył eksternistycznie 26 lutego 1887 roku w Chojnicach. Kolejnym etapem jego edukacji były studia teologiczne w Muenster i Monachium. Dokończył je w Wyższym Seminarium Duchownym w Pelplinie. Po ich zakończeniu 15 marca 1891 roku przyjął święcenia kapłańskie.

Jego pierwszą placówką duszpasterską była parafia w Śliwicach. Następnie był wikariuszem w Wielu. W 1894 roku został administratorem w Bobowie koło Brodnicy. W następnym roku biskup chełmiński mianował go wikariuszem w Lutowie, gdzie przebywał przez dwa lata. W kwietniu 1897 roku rozpoczął posługę duszpasterską w Brusach. Następnie przez krótki czas duszpasterzował jako wikary w Kielnie i Raciążu. W 1900 roku został administratorem parafii Srebrniki. W 1929 roku został jej proboszczem ${ }^{5}$. W swoim kapłańskim życiu ks. Feliks Bolt bardzo angażował się społecznie. Nigdy jednak nie zaniedbywał pracy duszpasterskiej. Jako wikariusz otaczał opieką duszpasterską emigrantów sezonowych, a więc robotników, którzy wczesną wiosną opuszczali swoje rodziny i udawali się do pracy w Niemczech. Do domów wracali późną jesienią ${ }^{6}$.

Jako proboszcz w Srebrnikach, ks. Feliks Bolt odnowił tamtejszy kościół. W parafii za jego czasów powstały też różne organizacje kościelne, takie jak Bractwo Serca Jezusowego oraz Stowarzyszenie Młodzieży Męskiej i Żeńskiej’. Proboszczem w Srebrnikach był do 24 października 1939 roku. Tego dnia został aresztowany przez gestapo w swojej parafii. Przez kilka miesięcy był więziony w różnych miejscach. W wyniku trudnych warunków bytowania zmarł z wycieńczenia 7 kwietnia 1940 roku$^{8}$.

\section{AKTYWNOŚĆ SPOŁECZNA}

Aktywność społeczna stanowiła ważną sferę życia ks. Feliksa Bolta. Wyrażała się ona m.in. w działalności na rzecz polskich organizacji społecznych i gospo-

3 Por. G. Szarmach, P. Kawczyński, Ksiądz Feliks Bolt. Patron Publicznej Szkoty Podstawowej w Barłożnie, Mirex, Barłożno 1996, s. 17.

4 Por. H. Mross, Stownik biograficzny kapłanów diecezji chetmińskiej wyświęconych w latach 1821-1920, Bernardinum, Pelplin 1995, s. 20.

5 Por. P. Kotewicz, Oni swój ślad tu zostawili, Bernardinum, Pelplin 1998, s. 34.

6 Por. Feliks Bolt - ksiadz (1864-1940), www.brusy.pl/t_pliki_/1155.doc (27.6.2018).

7 Por. A. Grzyb, P. Dworak, Ksiadz Feliks Bolt-niezłomny Pomorzanin, http://www.mapakultury. pl/art,pl,mapa-kultury,95120.html (28.6.2018).

8 Por. tamże. 
darczych na Pomorzu. W swojej aktywności w życiu społecznym realizował zasadę pracy organicznej, która polegała na podniesieniu poziomu gospodarczego, oświaty oraz kultury materialnej i duchowej narodu polskiego pod zaborami. Praktyki pracy organicznej ks. Bolt nauczył się od swojego pierwszego proboszcza w Śliwicach - ks. Teofila Krzeszowskiego. Był to wielki działacz społeczny, który zorganizował wiele stowarzyszeń społecznych, spółek i banków na Pomorzu. Od niego młody wikariusz mógł wynieść zdolności organizacyjne9. Przydały one się szczególnie w szóstym roku kapłaństwa ks. Feliksa Bolta, kiedy to trafił on do Brus jako wikariusz. Miejscowość ta była silnym ośrodkiem polskiej działalności gospodarczej i tutaj bardzo szybko nawiązał współpracę z ziemianami z Wielkich Chełmów Stanisławem i Anną Sikorskimi ${ }^{10}$. Ta wszechstronna współpraca między ks. Boltem a ziemianinem z Wielkich Chełmów trwała przez długie lata. Stanisław Sikorski, będąc prezesem Banku Ludowego i ówczesny wikariusz bruski ks. Bolt, 24 stycznia 1898 roku, zawiązali spółkę o pełnej nazwie: „Kupiec”. Jej twórcy stworzyli ją z zamiarem wyeliminowania z handlu bławatnego i tekstylnego Niemców. W pierwszym roku swojego działania „Kupiec” liczył 359 członków, trzy lata później 2991, a w 1905 roku 3738 udziałowców ${ }^{11}$. Szybko rozwijający się „Kupiec” objął swoim zasięgiem północną część Pomorza. Ta prężnie rozwijająca się spółka odebrała rynek tekstylny firmom niemieckim i żydowskim w okolicach Śliwic, Wiela i Zblewa ${ }^{12}$. W latach 1898-1899 powstały filie spółki w Wielu i Śliwicach. W 1900 roku założona została filia w Zblewie, a rok później w Starej Kiszewie. W 1904 roku, aby poszerzyć działalność spółki „Kupiec”, jej twórcy powołali nową spółkę, jako towarzystwo akcyjne „Bazar”. Miało ono swoją siedzibę również w Brusach ${ }^{13}$. Wkrótce powstały filie tej spółki w Pelplinie, Bytowie i Kartuzach. Ostatnia z tych miejscowości stała się siedzibą centrali ${ }^{14}$.

Innym wyrazem zaangażowania społecznego ks. Bolta była działalność w Centralnym Towarzystwie Rolniczym dla Prus Zachodnich. W 1900 roku był jego głównym organizatorem. W jego władzach pełnił funkcję wiceprezesa i sekretarza. Zadaniem tego stowarzyszenia było organizowanie małych rolników i wielkich właścicieli ziemskich w kółka rolnicze i spółki, aby podnieść przez to poziom rolnictwa i jego dochodowość. Pomogło też ono ocalić niejedno polskie gospodarstwo od upadku i przejęcia przez Niemców. Sam ks. Bolt przyczynił się do powstania kilkunastu kółek rolniczych. Jedno z nich 7 lipca 1901 roku powstało w Brusach. Działalność tego bruskiego kółka rolniczego przyczyniła się do popu-

\footnotetext{
9 Por. G. Szarmach, P. Kawczyński, dz. cyt., s. 19.

10 Por. tamże.

11 Por. J. Borzyszkowski, W państwie prusko-niemieckim, w: Historia Brus i okolicy, red. J. Borzyszkowski, Bernardinum, Brusy - Gdańsk 2006, s. 338.

12 Por. Feliks Bolt - ksiadz (1864-1940), dz. cyt.

13 Por. tamże.

14 Por. ks. P. Kotewicz, dz. cyt., s. 34.
} 
laryzacji wiedzy fachowej za pomocą odbywających się odczytów. W ramach jego działań wydawano specjalistyczne broszury oraz gazety opisujące praktyczne porady odnośnie do upraw i gospodarowania nimi. Dzięki tego typu działalności było możliwe wprowadzenie nowych upraw i metod gospodarowania. Działalność kółka rolniczego w Brusach zwiększyło również zainteresowanie chłopów stosowaniem nawozów sztucznych i maszyn. Organizowano też wymianę doświadczeń $^{15}$. W ramach działalności Centralnego Towarzystwa Rolniczego w 1901 roku powstała spółka prowadząca handel artykułami rolniczymi, pod nazwą „Rolnik”, w Pelplinie z czasową siedzibą w Toruniu. Jej zasięg obejmował teren całych Prus Zachodnich. Spółka ta istniała do 1912 roku. Prezesem Rady Nadzorczej spółki był Stanisław Sikorski, a dyrektorem zarządu ks. Feliks Bolt ${ }^{16}$. Ten ostatni, przez swoje zaangażowanie $\mathrm{w}$ działalność handlową, został nazwany zaszczytnym mianem „ojca kupiectwa polskiego na Pomorzu”. Powszechnie uważano go za najwybitniejszego eksperta w dziedzinie zakładania spółek handlowych ${ }^{17}$. Od 1904 roku ks. Feliks Bolt, dzięki swojemu zaangażowaniu w tej dziedzinie, został członkiem Patronatu Związku Spółek Zarobkowych w Poznaniu, a także bliskim współpracownikiem ks. Piotra Wawrzyniaka ${ }^{18}$. W latach 1922-1934 w związku tym pełnił funkcję wiceprezesa. Z kolei w latach 1917-1931 był członkiem Rady Nadzorczej Banku Związku Spółek. Wcześniej, w latach 1906-1915 ks. Feliks Bolt był najpierw wiceprezesem, a potem prezesem Rady Nadzorczej Banku Ludowego w Kowalewie Pomorskim ${ }^{19}$.

Zaangażowanie społeczne ks. Feliksa Bolta wyrażało się też w jego wkładzie w powstanie spółek zajmujących się wydawaniem prasy polskiej. Chodzi tutaj o takie gazety jak: „Gazeta Polska”, „Gazeta Chojnicka” i pelpliński „Pielgrzym”. 17 lutego 1920 roku przyczynił się do powstania spółki akcyjnej dla wydawania „Gazety Gdańskiej”. Był akcjonariuszem tej spółki i pełnił w niej funkcję przewodniczącego Rady Nadzorczej. W Chojnicach był organizatorem i udziałowcem Chojnickiej Polskiej Spółki Wydawniczej „Gazety Chojnickiej”. Pierwszy numer tego pisma powstał w 1912 roku $^{20}$. Ks. Felis Bolt był również współpracownikiem pelplińskiego „Pielgrzyma” i stał się, wraz z innymi księżmi, współtwórcą opiniotwórczej roli tej gazety. W swoich artykułach na łamach „Pielgrzyma” przypominał o polskości Prus Zachodnich. Zabiegał też o wzmocnienie więzi łączących społeczność polską na Pomorzu. Przypominał również Polakom o ich obowiązkach narodowych. Pisząc na łamach pelplińskiego periodyku o zagrożeniach, jakie czyhają na Polaków w dzielnicy pomorskiej zaboru pruskiego, podkreślał, że

15 Por. Feliks Bolt - ksiądz (1864-1940), dz. cyt.

16 Por. tamże.

17 Por. tamże.

18 Por. A. Grzyb, P. Dworak, dz. cyt.

19 Por. Feliks Bolt - ksiadz (1864-1940), dz. cyt.

20 Por. tamże. 
najbardziej niebezpieczni są ci, których określał mianem „sprzedawczyków, zdrajców i wyrodnych synów ojczyzny"21.

Ks. Feliks Bolt angażował się również w działalność Związku Kapłanów „Unitas”. W latach 1924-1926 był członkiem zarządu głównego tej organizacji22. W ramach działalności związku „Unitas” dla diecezji chełmińskiej, w 1925 roku, pojawiła się inicjatywa wybudowania własnego uzdrowiska nad morzem. Pierwotnie miało być ono wybudowane w Jastrzębiej Górze, jednak na nadzwyczajnym zebraniu organizacji, jakie miało miejsce 7 lutego 1927 roku w Pelplinie, uchwalono, że miejscem budowy uzdrowiska będzie Orłowo. Aby realizacja tego przedsięwzięcia była możliwa, zawiązała się specjalna spółka z ograniczoną odpowiedzialnością, o nazwie „Księżówka Bałtycka”. Jej zadaniem był zakup i utrzymanie nad Morzem Bałtyckim domów kuracyjnych dla członków spółdzielni. Powstał też statut normujący zasady jej działania, który został zatwierdzony 10 marca 1927 roku przez Sąd Powiatowy w Tczewie. Powołano też zarząd i radę nadzorczą „Księżówki Bałtyckiej”. W radzie nadzorczej znalazł się ks. Feliks Bolt, obok księży: Adama Kupczyńskiego, ks. Franciszka Filarskiego, ks. Franciszka Roszczynialskiego i ks. Juliusza Felskiego. W 1930 roku opisywana spółdzielnia została przyjęta do Związku Spółdzielni Zarobkowych i Gospodarczych w Poznaniu. Liczyła wtedy 84 członków. Pomimo ciągłego wzrostu liczby członków spółdzielni oraz wsparcia finansowego z innych źródeł spółdzielnia „Księżówka Bałtycka” nie zdołała w pełni rozwinąć swojej działalności. Było to związane z powstaniem domu rekolekcyjnego dla kapłanów w Bierzgłowie oraz niedoborem gotówki ze względu na kryzys finansowy ${ }^{23}$.

Proboszcz ze Srebrników, jako dawny filomata z czasów zaborów, był zaangażowany w powstanie Związku Filomatów Pomorskich. Powstał on w 1921 roku w Chełmnie. Ks. Feliks Bolt był też członkiem powstałego w 1926 roku Bractwa Pomorskiego w Toruniu oraz Towarzystwa Badania Ruchu Niepodległościowego na Pomorzu. Zostało ono powołane w 1930 roku $^{24}$.

Zaangażowanie społeczne księdza Feliksa Bolta było bardzo bogate i wyrażało się na wielu płaszczyznach, między innymi w organizacjach społecznych, patriotycznych i gospodarczych. Ważnym wyrazem działalności społecznej „ojca kupiectwa polskiego na Pomorzu", a dla innych wzoru osobowości Pomorzanina była jego działalność polityczna.

21 Por. tamże.

22 Por. tamże.

23 Por. ks. J. Walkusz, Duchowieństwo katolickie diecezji chetmińskiej 1918-1939, Bernardinum, Pelplin 1992, s. 183-184.

24 Por. Feliks Bolt-ksiądz (1864-1940), dz. cyt. 


\section{ZAANGAŻOWANIE POLITYCZNE KS. FELIKSA BOLTA}

Zaangażowanie polityczne ks. Feliksa Bolta rozpoczęło się już przed pierwszą wojną światową. W 1913 roku została wysunięta jego kandydatura na posła. Startował w wyborach jako prezes Towarzystwa Wyborczego w Wąbrzeźnie i członek Prowincjonalnego i Centralnego Komitetu Wyborczego. Podczas wyborów nie został jednak wybrany. To niepowodzenie jednak nie osłabiło jego działalności politycznej ${ }^{25}$. Po wybuchu pierwszej wojny światowej działał jako członek Tajnego Komitetu Międzypartyjnego, który koordynował działalność sił antyniemieckich. Oprócz ks. Bolta do powyższego komitetu należeli: ks. Antoni Wolszlegier, Stefan Łaszewski oraz Leon Jarota-Połczyński²6. Od lipca 1918 roku działał w Centralnym Komitecie Obywatelskim, który w listopadzie tegoż roku przekształcił się w Naczelną Radę Ludową. Ks. Bolt był też uczestnikiem obrad Sejmu Dzielnicowego w Poznaniu. Współpracował przez cały czas z Romanem Dmowskim będąc jednym z czołowych działaczy endecji na Pomorzu ${ }^{27}$. W latach 1920-1928 był przywódcą tutejszego obozu narodowego pełniąc funkcję prezesa Rady Wojewódzkiej Związku Ludowo-Narodowego, a po jego przekształceniu w Stronnictwo Narodowe w latach 1928-1935 został jego prezesem w województwie pomorskim. Od roku 1935 był członkiem Komitetu Głównego tego ugrupowania $^{28}$.

8 czerwca 1920 roku rozpoczęła się działalność parlamentarna ks. Bolta. Otrzymał wtedy mandat posła na Sejm Ustawodawczy w wyborach uzupełniających z dnia 2 maja 1920 roku. W ramach działalność parlamentarnej był członkiem Komisji Pomorskiej. Następnie został włączony w działalność Komisji Morskiej. Był też zastępcą komisarza w polsko-gdańskiej komisji granicznej. Ksiądz Bolt uczestniczył w organizowaniu pomocy dla powstańców śląskich i wielkopolskich. Jako poseł przyczynił się do budowy linii kolejowej z Bydgoszczy do Gdyni. W 1922 roku ks. Feliks Bolt został senatorem z ramienia Związku Ludowo-Narodowego na pięcioletnią kadencję. W tym czasie był też członkiem Komisji Skarbowo-Budżetowej. W latach 1930-1935 „ojciec kupiectwa polskiego” był senatorem z ramienia Stronnictwa Narodowego. 11 grudnia 1930 roku został wicemarszałkiem Senatu oraz przewodniczącym Komisji Gospodarstwa Społecznego i Komisji Skarbowo-Budżetowej. Powszechnie był uważany za senatora ludu pomorskiego, którego był rzecznikiem ${ }^{29}$.

25 Por. A. Grzyb, P. Dworak, dz. cyt.

26 Por. G. Szarmach, P. Kawczyński, dz. cyt., s. 21.

27 Por. A. Grzyb, P. Dworak, dz. cyt.

28 Por. Feliks Bolt - ksiadz (1864-1940), dz. cyt.

29 Por. A. Grzyb, P. Dworak, dz. cyt. 


\section{MARTYROLOGIA KSIĘDZA FELIKSA BOLTA}

Po wybuchu drugiej wojny światowej rozpoczęły się masowe aresztowania Polaków, m.in. kapłanów. Dotknęły one też ks. Feliksa Bolta. Został on aresztowany w Srebrnikach dokładnie 24 października 1939 roku $^{30}$. Na początku był więziony w Dębowej Łące ${ }^{31}$, gdzie w Domu Zgromadzenia Sióstr Pasterek od Opatrzności Bożej gestapo zorganizowało jeden z obozów zbiorczych. Aresztowani tam księża zostali umieszczeni w dwóch pokojach. Po dwóch tygodniach, po wizycie Gauleitera Forstera 7 listopada 1939 roku, księża mogli chodzić na przechadzki w parku i mogli celebrować msze św. Następnym miejscem przetrzymywania ks. Feliksa Bolta było Chełmno, gdzie aresztowani księża zostali umieszczeni w klasztorze sióstr szarytek na pierwszym piętrze. Został tam przewieziony wraz z dwunastoma innymi księżmi 6 grudnia 1940 roku $^{32}$. Stąd 21 marca 1940 roku przewieziono go wraz z innymi więźniami do obozu koncentracyjnego KL Stutthoff ${ }^{33}$. Obóz ten w początkach 1940 roku stał się centralnym obozem gromadzącym aresztowanych kapłanów z diecezji położonych na Pomorzu. W obozie tym przetrzymywani byli też więźniowie cywilni. Jak relacjonuje ks. Feliks Windorpski w swoich wspomnieniach po przybyciu do Stutthofu więźniowie musieli zeskakiwać z samochodu i przejść przez szpaler stworzony przez SS-manów z kijami i gumowymi pałkami, którymi bili nowo przybyłych. Na noc zostali oni umieszczeni w pustym baraku. Kiedy następnego dnia postawiono więźniów przed barakiem, przejścia poprzedniego dnia tak odbiły się na nich, że trudno było ich rozpoznać, m.in. ks. Feliksa Bolta ${ }^{34}$. Po ich spisaniu po raz kolejny zostali okrutnie pobici i wyznaczono ich do ciężkich prac przy nędznych racjach żywnościowych ${ }^{35}$. Te trudne warunki spowodowały, że ks. Feliks Bolt podupadł

${ }_{30}$ Jak opisuje ks. Feliks Windorpski, w nocy z 24 na 25 października w powiecie wąbrzeskim, w którym leżały Srebrniki, zburzono wszystkie figury i krzyże przydrożne. Tej nocy aresztowano 18 księży z dekanatu golubskiego i wąbrzeskiego. Byli to: ks. Józef Prohnke z Kurkocina, ks. Roman Galikowski - wikariusz z Kurkocina, ks. Jarzębski z Lipnicy, ks. Konstantyn Licznierski z Pluskowęs, ks. Władysław Łęgowski z Radowisk, ks. Bronisław Kownacki z Golubia, ks. Franciszek Ruciński - wikariusz z Golubia, ks. Tadeusz Andrzejewski z Zielenia, ks. Edmund Konnak z Dębowej Łąki, ks. Franciszek Bączkowski z Nowejwsi, ks. Józef Wilemski z Orzechowa, ks. Franciszek Dekowski z Płużnicy, ks. Feliks Bach-Żelewski z Ryńska, ks. Feliks Zaremba z Wąbrzeźna, ks. Alfons Gończ - wikariusz z Kowalewa, ks. Władysław Homa z Ostrowitego i ks. Feliks Windorpski z Osieczka. Zob. J. Sziling, Z dziejów martyrologii duchowieństwa diecezji chetmińskiej. Wspomnienia księdza Feliksa Windorpskiego z niemieckich obozów koncentracyjnych, „Zapiski historyczne” 80(2015), s. 257.

31 Por. Feliks Bolt - ksiadz (1864-1940), dz. cyt.

32 Por. J. Sziling, dz. cyt., s. 257.

33 Por. Feliks Bolt - ksiadz (1864-1940), dz. cyt.

34 Por. J. Sziling, dz. cyt., s. 257.

35 Por. tamże. 
na zdrowiu, co w konsekwencji doprowadziło do jego śmierci. Zmarł z wycieńczenia 7 kwietnia 1940 roku.

Ostatnie chwile jego życia opisuje dokładnie ks. Wojciech Gajdus we wspomnieniach obozowych: „Na rewir przywożą ks. Feliksa Bolta, starca 75-letniego, wybitnego działacza pomorskiego, posła i senatora Rzeczypospolitej. Układają go na barłogu. Wkrótce kończy życie. Nazwisko jego to historia. Historia walki wpierw z Niemcami o polski stan posiadania, o prawo bytu, o prawo do języka i kultury polskiej. Ksiądz Bolt to pomorski Wawrzyniak, tytan czynu i pracy. Całe jego życie jest walką i to walką aż do końca o polskie Pomorze. Bezkompromisowy, przystępny wszystkim ludzkim uczuciom. Jednego tylko nie zna uczucia, strachu... Był wielki. Osobiście na Polsce nie dorobił się ani majętności, ani zaszczytu. Siedział na małej parafii w Srebrnikach pod Kowalewem Pomorskim nie odznaczony ni odznakami kościelnymi, ni państwowymi, lecz był wielki, większy nad wszystkie ludzkie zaszczyty i dostojeństwa. Bogaty w szacunek, miłość ludu pomorskiego, którego był rzecznikiem u tronu Rzeczypospolitej, a orędownikiem u Boga. Wprowadzono go przez próg jako 75-letniego staruszka z honorami jak kanonika nowo mianowanego do stalli. Górował i tu. I tu był panem, senatorem Rzeczypospolitej. I tu wzbudzał szacunek. Do trumny złożyli go ci, dla których żył - młodzi Polacy. Niosą go przez dziedziniec do samochodu ciężarowego. Mija nasze okna wysoko wzniesiona trumna. Nie ma wieńców, przemów, księży, proporców. Żył skromnie i tak go chowają. Męża z jednej bryły senatora Rzeczypospolitej. Ukochaniem jego była Polska, a celem Bóg"36.

\section{PODSUMOWANIE}

Ks. Feliks Bolt na trwałe wpisał się w historię Pomorza i Polski. W swoim kapłańskim życiu, żyjąc skromnie, poświęcił się posłudze duszpasterskiej i służbie ojczyźnie. Przez wielorakie zaangażowanie przyczynił się do umacniania ducha polskości w parafiach, w których pracował. Dzięki wytrwałości odnosił sukcesy w dziedzinie zakładania spółek handlowych. Przez organizowanie chłopstwa i ziemiaństwa w kółka rolnicze wpłynął na podniesienie poziomu rolnictwa. Ks. Feliks Bolt był też aktywny politycznie piastując zaszczytne funkcje posła i senatora Rzeczypospolitej. Przez swoje zaangażowanie ks. Bolt wpłynął istotnie na powstanie takich polskich gazet jak: „Gazeta Gdańska”, „Gazeta Chojnicka” i pelpliński „Pielgrzym”. Bardzo dobrze życie i posługę ks. Bolta oddają słowa z jego artykułu zamieszczonego w 14 numerze „Pielgrzyma” z 1930 roku. Pisał on wtedy tak o sobie i kapłanach jemu podobnych: „Nie pracujemy ani dla jednostki, ani dla partii, ani dla nagrody, ani dla zaszczytów - lecz dla narodu i Ojczy-

36 Por. S. Podlewski, dz. cyt., s. 145. 
zny według przykazań religii naszych przodków"37. Zaangażowanie społeczne ks. Feliksa Bolta sprawiło, że pamięć o nim jest ciągle żywa w Barłożnie, z którego pochodził i w miejscowościach, w których posługiwał. Wyrazem tego jest chociażby to, że publiczna szkoła podstawowa w jego rodzinnej miejscowości nosi jego imię. Ponadto znajduje się tam izba pamięci poświęcona patronowi. W Brusach, gdzie był wikariuszem, jedna z ulic jest nazwana jego imieniem i nazwiskiem.

\section{Bibliografia}

Borzyszkowski J., W państwie prusko-niemieckim, w: Historia Brus i okolicy, red. J. Borzyszkowski, Bernardinum, Brusy - Gdańsk 2006, s. 181-466.

Feliks Bolt-ksiadz (1864-1940), www.brusy.pl/t_pliki_/1155.doc (27.6.2018).

Grzyb A., Dworak P., Ksiadz Feliks Bolt-niezłomny Pomorzanin, http://www. mapakultury.pl/art,pl,mapa-kultury,95120.html (28.6.2018).

Kotewicz P., Oni swój ślad tu zostawili, Bernardinum, Pelplin 1998.

Mross H., Stownik biograficzny kapłanów diecezji chetmińskiej wyświęconych w latach 1821-1920, Bernardinum, Pelplin 1995, s. 20-21.

Podlewski S., Wierni Bogu i Ojczyźnie, Novum, Warszawa 1982, s. 145.

Szarmach G., Kawczyński P., Ksiądz Feliks Bolt. Patron Publicznej Szkoty Podstawowej w Barłożnie, Wyd. Mirex, Barłożno 1996.

Sziling J., Z dziejów martyrologii duchowieństwa diecezji chetmińskiej. Wspomnienia księdza Feliksa Windorpskiego z niemieckich obozów koncentracyjnych, „Zapiski historyczne” 80(2015), s. 256-278.

Walkusz J., Duchowieństwo katolickie diecezji chetmińskiej 1918-1939, Bernardinum, Pelplin 1992.

Wielgoszewski W., Męczeństwo kapłanów Kościoła chełmińskiego. Wierni aż do końca, „Niedziela” 45(2006), s. 21.

\section{Streszczenie}

Jednym ze znanych działaczy społecznych na Pomorzu jest ks. Feliks Bolt. Urodził się 7 stycznia 1863 roku w Barłożnie. Kształcił się w pelplińskim Collegium Marianum i w gimnazjum w Chełmnie. Egzamin dojrzałości zdał w Chojnicach. 15 marca 1891 roku przyjął święcenia kapłańskie. Pracował w następujących parafiach: Śliwice, Wiele, Bobowo, Lutowo, Brusy, Kielno, Raciąż i Srebrniki. W tych ostatnich był proboszczem od 1929 roku. Jako kapłan umiejętnie łączył pracę duszpasterską z zaangażowaniem społecznym. W swojej parafii w Srebrnikach zakładał różne stowarzyszenia kościelne i odnowił tamtejszy kościół. Wyrazem jego zaangażowania społecznego są zakładane przez niego różne spółki

37 Zob. G. Szarmach, P. Kawczyński, dz. cyt., s. 19. 
handlowe, m.in. „Kupiec” i „Rolnik”. Za swoje zaangażowanie został uznany „ojcem kupiectwa polskiego na Pomorzu”. Ksiądz Feliks Bolt działał też w Centralnym Towarzystwie Rolniczym dla Prus Zachodnich, które stało się inspiracją do powstawania kółek rolniczych. Dzięki tego typu działalności udało się podnieść poziom rolnictwa i jego dochodowość. Innym ważnym wymiarem działalności społecznej ks. Bolta było jego zaangażowanie polityczne. Był jednym z czołowych działaczy endecji na Pomorzu. Był posłem na Sejm Ustawodawczy, a w 1922 roku został senatorem. Funkcję tę piastował do 1935 roku. Wkrótce po wybuchu drugiej wojny światowej został aresztowany przez gestapo. Był więziony kolejno w Dębowej Łące, Chełmnie i Stutthofie. Ciężkie warunki obozowe sprawiły, że upadł na zdrowiu i zmarł 7 kwietnia 1940 roku.

Slowa kluczowe: ksiadz Feliks Bolt, filomata, studia teologiczne, Srebrniki, spótka handlowa, dziatalność parlamentarna, Stutthof.

Feliks Bolt - a Pastor, a Patriot, a Social Activist

\section{Summary}

Rev. Feliks Bolt, born in Barlozno on 7 January 18, is a famous Pomeranian social activist. Educated in Collegium Marianum, Chelmno and Chojnice he received the priestly ordination on 15 March 1891. Then Rev. Bolt worked as a curate and finally as a parish priest in Srebrniki since 1929. As a true shepherd of his flock he successfully combined the pastoral work with his social activity. He founded various religious associations as well as commercial enterprises for which Feliks Bolt was named the father of the Polish entrepreneurship in Pomerania. As an active member of the Agricultural Society of Western Prussia he fostered the creation of numerous farmers' unions. Rev. Bolt belonged to the Polish national movement in Pomerania and was elected as an MP and a senator. At the beginning of the Second World War he was arrested by the Gestapo and imprisoned in Debowa Laka, Chelmno and Stutthof. The harsh concentration camp conditions weakened his health which led to his death on 7 April 1940.

Keywords: Rev. Feliks Bolt, Philomaths, Theological studies, Srebrniki, enterprise, parliamentary activity, Stutthof 